\title{
AVALIAÇÃO DA DISTRIBUIÇÃO DE PÓLOS GEOMAGNÉTICOS VIRTUAIS PARA UM CAMPO NÃO EXCLUSIVAMENTE DIPOLAR
}

\author{
Everton Frigo \\ Orientador: Dra. Marcia Ernesto (IAG/USP) \\ 93 p. - Dissertação (Mestrado) - Defesa 24.04.2008
}

\begin{abstract}
RESUMO. As variações de longo período do campo geomagnético são estudadas através de dados provenientes do registro do campo antigo nas rochas. A direção de magnetização obtida de um certo nível estratigráfico, ou de um derrame de lava, corresponde a um instante no tempo geológico e marca a posição que o pólo magnético da Terra ocupava no momento de formação da rocha em consideração. Essa direção é transformada num pólo geomagnético virtual (PGV) e uma sucessão de eventos geológicos deve fornecer uma série de PGVs que descrevem a trajetória do pólo magnético terrestre durante 0 intervalo de tempo correspondente. Este trabalho visa avaliar a distribuição de dados paleomagnéticos para um campo não exclusivamente dipolar, usando-se dados obtidos de sucessões de derrames de lava e de intrusões ígneas. São abordados dois pontos principais: (1) a forma da distribuição dos dados e seus parâmetros estatísticos no caso de haver controle cronológico dos eventos geomagnéticos registrados e no caso de controle ausente; (2) possíveis efeitos de componentes não dipolares do campo geomagnético sobre as distribuições de direções e de pólos geomagnéticos virtuais. Os dados paleomagnéticos utilizados foram obtidos em seções geológicas da Formação Serra Geral provenientes das partes sul (idades de $\sim 133 \mathrm{Ma}$ ), e das partes central e norte (idades de $\sim 132 \mathrm{Ma}$ ), da Bacia do Paraná. Os dados geomagnéticos utilizados foram obtidos a partir do modelo IGRF 2005. Além disso, foram utilizados dados sintéticos calculados a partir do modelo do dipolo geocêntrico axial. Os valores da dispersão angular dos dados paleomagnéticos são, em geral, menores que aqueles previstos em modelos de variação paleossecular (modelo G) para 0 intervalo de 110-195 Ma e, embora também menores, aproximam-se mais dos valores previstos no modelo para o intervalo 0-5 Ma. Conclui-se que, em geral, quando os dados apresentam distribuições fisherianas, a dispersão angular é menor do que para distribuições não-fisherianas o que pode justificar a discrepância entre os valores encontrados e aqueles previstos no modelo. Os dados não-transicionais, em seções com bom controle cronológico, concentram-se em três bandas de longitude: $60-90^{\circ} \mathrm{E}, 120-150^{\circ} \mathrm{E}$ e 240-270E, sendo que a segunda concorda com uma das bandas preferenciais de longitude sugeridas na literatura para PGVs transicionais dos últimos 12Ma. As distribuições dos conjuntos de PGVs não transicionais, que apresentam bandas preferenciais de longitude, são do tipo não-fisherianas, sendo as demais fisherianas. Os resultados obtidos a partir dos dados geomagnéticos indicam que, quanto maior a presença de componentes não dipolares do campo, maior serão as distorções produzidas nas distribuições de direções e de PGVs. Se uma anomalia de campo não dipolar afetar uma região por um período suficientemente longo para haver registro paleomagnético de todo, ou parte, do ciclo de variação secular, haverá distorções significativas no conjunto de dados resultante.
\end{abstract}

ABSTRACT. The long period variations of the geomagnetic field are studied through records of the ancient field in rocks. The magnetization direction obtained for a certain stratigraphic level or lava flow corresponds to an instant in the geological time, and marks the position the magnetic pole was occupying at the time the rock was formed. That direction is transformed into a virtual geomagnetic pole (VGP) and successive geologic events provide a series of VGPs that describe the trajectory of the Earth's magnetic pole during the corresponding time interval. This work intends to evaluate the distribution of paleomagnetic data for a non-exclusive dipolar field by means of data obtained from successive lava flows and intrusive rocks. Two main points will be addressed: (1) the shape distribution of data and its statistical parameters in case of existing chronological control of the recorded geomagnetic events, and in case of no control; (2) possible effects of non-dipolar components of the geomagnetic field on the direction and VGP distributions. The paleomagnetic data used in this work come from geological sections of the Serra Geral Formation in the Paraná Basin, exposed in the south area (ages around 133Ma), and in the central and north areas (ages around 132Ma). Geomagnetic data are from the IGRF 2005 model. Synthetic data was also used, and was calculated based on the geocentric axial dipole model. The angular dispersion values obtained from paleomagnetic data are, in general, smaller than those proposed in paleosecular variation models (model G) for the age interval 110-195 Ma, but closer to the 0-5 Ma age interval. It is concluded that when data has fisherian distribution the angular dispersion is smaller than for non-fisherian distributions. This may justify the discrepancy between the expected values from statistical models and those obtained for real cases. Non-transitional data concentrate in three longitude bands: $60-90^{\circ} \mathrm{E}, 120-150^{\circ} \mathrm{E}$ and $240-270^{\circ} \mathrm{E}$, the second being in agreement with one of the proposed longitude bands in literature for transitional VGPs for the last $12 \mathrm{Ma}$. Those data sets including non-transitional VGPs that show longitude band confinement corresponds to non-fisherian distributions, whereas the others are fisherian. Results from geomagnetic data indicate that the stronger the presence of non-dipolar components the greater will be the distortion in the distributions of directions and VGPs. If a non-dipolar field anomaly affects an area for a sufficient time interval to generate a paleomagnetic record of a secular variation cycle, or part of it, than significant distortions in the resulting data set will appear. 